Eur. J. Clin. Chem. Clin. Biochem.

Vol. 32, 1994, pp. 319-326

(c) 1994 Walter de Gruyter \& Co.

Berlin · New York

\title{
Influence of Electromagnetic Fields on the Enzyme Activity of Rheumatoid Synovial Fluid Cells in vitro
}

\author{
By H. Mohamed-Ali ${ }^{1}$, H. Kolkenbrock ${ }^{2}$, N. Ulbrich ${ }^{2}$, H. Sörensen ${ }^{3}$, K. D. Kramer ${ }^{4}$ and H.-J. Merker ${ }^{1}$ \\ 1 Institut für Anatomie, Freie Universität Berlin, Germany \\ 2 Institut für Biochemie, Freie Universität Berlin, Germany \\ 3 Immanuel-Krankenhaus, Abt. für Rheumatologie, Berlin, Germany \\ ${ }^{4}$ Institut für Experimentalphysik, Freie Universität Berlin, Germany
}

(Received August 11/December 16, 1993)

Dedicated to Prof. Dr. Dr. Helmut Greiling on the occasion of his 65 th birthday

Summary: Since positive clinical effects have been observed in the treatment of rheumatoid arthritis with electromagnetic fields of weak strength and low frequency range (magnetic field strength: $70 \mu \mathrm{T}$; frequency: $1.36-$ $14.44 \mathrm{~Hz}$ ), an attempt was made to analyse the effects of these electromagnetic fields on enzyme activity in monolayer cultures of rheumatoid synovial fluid cells after single irradiation of the cultures for 24 hours. We only investigated the matrix metalloproteinases (collagenase, gelatinase, proteinase 24.11 and aminopeptidases). It was found that electromagnetic fields of such a weak strength and low frequency range do not generally have a uniform effect on the activity of the different proteinases in vitro. While aminopeptidases do not show any great changes in activity, the peptidases hydrolysing $\mathrm{N}(2,4)$-dinitrophenyl-peptide exhibit a distinct increase in activity in the late phase in culture medium without fetal calf serum. In the presence of fetal calf serum this effect is not observed and enzyme activity is diminished.

Our experiments do not show whether such a phase-bound increase in the activity of proteinases in vitro is only one finding in a much broader range of effects of electromagnetic fields, or whether it is a specific effect of weak pulsed magnetic fields of $285 \pm 33 \mathrm{nT}$ on emzyme activity after single irradiation. This question requires further elucidation.

\section{Introduction}

Synovial cells display pronounced enzymatic activities in rheumatoid arthritis (1), which they largely maintain in vitro though to a lesser extent in man than in animals (2). These enzymatic activities therefore appear to be suitable quantities for investigating the behaviour of synovial cells under different conditions. Activity measurements of the various proteinases and peptidases in the culture medium of rheumatoid synovial cells proved to be a relatively simple and reproducible method for investigating different chemical and physical influences on the activity of these cells. This is further facili- tated by the extracellular occurrence of neutral proteinases, especially collagenase, which can therefore be determined in the culture medium (3). The effect of electromagnetic fields on the synthesis and activity of enzymes has been investigated extensively in animal experiments in vivo, in tissue extracts from different animals, in enzyme substrate solutions (4), and recently to an increasing extent in cell and tissue cultures $(5,6)$.

In vivo experiments revealed a reversible reduction of the enzyme activity after single exposure to electromagnetic fields and a biphasic change in activity after repeated exposure (initial reduction and a later increase). 
This was shown for amylase, lipase, catalase and peroxidase in the blood of guinea pigs and rabbits that were treated with high field strength $(1-20 \mathrm{~V} / \mathrm{cm})$ and high frequency (SHF-UHF: $8 \mathrm{kHz}-27 \mathrm{MHz}$ ) once (for 20 min) or several times a day (for $20 \mathrm{~min}$ each) at 2-day intervals (7-9).

In vitro experiments also showed a reduction in enzyme activity; a biphasic change in activity, similar to that in the in vivo experiments, was not, however, observed. In solutions of some enzymes, such as lysozymes, $\alpha$-amylase, catalase and peroxidase, a clear-cut decrease in activity due to the effects of electromagnetic fields (field strength: $50-72 \mathrm{~V} / \mathrm{cm}$ and frequency: $8-20 \mathrm{MHz}$ ) was measured. In cultures of synovial fibroblasts and monocytes/macrophages, the most marked effect was the decreased release of two lysosomal enzymes, glucuronidase and $\mathrm{N}$-acetyl-glucosaminidase (5).

Long-term treatment with pulsed magnetic fields reduced the enzyme concentration in the culture media by as much as $50 \%$. But the metalloproteinases remained unchanged (10). Despite this peculiar response of the collagenolytical enzymes to pulsed magnetic fields, long-term treatment (10-14 days) led to an increase of collagen. This finding, which was confirmed with bone marrow- and tendon fibroblast-cultures, can be attributed to two mechanisms (10):

1) Reduced intra- and intercellular degradation of collagen due to a decrease of intracellular lysosomal enzymes and intercellular cAMP which is of particular importance for extracellular collagenolysis.

2) Shift in the balance of collagen metabolism in favour of synthesis.

Both mechanisms invoke the role of intracellular lysosomal enzymes. Since collagen is degraded by metalloproteinases (collagenase, gelatinase, aminopeptidase etc.) mainly in the extracellular space (11), the significance of intracellular enzymes in the long-term treatment with pulsed magnetic fields cannot be evaluated with certainty.

Closer examination of the effect of electromagnetic fields on such enzyme systems might.provide useful information on collagen metabolism under pathological conditions. Based on these considerations and stimulated by therapeutic reports on the positive effect of electromagnetic fields on patients with rheumatoid arthritis, osteoarthritis, spondylosis etc., we investigated the effect of electromagnetic fields (field strength: $70 \mu \mathrm{T}$, frequency: $1.36-14.44 \mathrm{~Hz}$ ) on cells of synovial fluid (in monolayer culture) from patients suffering from rheumatoid arthritis.

\section{Materials and Methods}

Materials

Synovial fluid was obtained from 14 patients suffering from rheumatoid arthritis (Rheuma-Klinik, Immanuel-Krankenhaus, Berlin). Synthetic substrates (Ala-p-nitranilide, N(2,4)-dinitrophenyl-peptide) were obtained from Bachem, Heidelberg, Germany. Mersalylic acid, 3-aminophenylmercury acktate, phosphoramidon and molecular mass markers for SDS-PAGE were purchased from Sigma.

Antibodies against human PMNL- and fibroblast gelatinases were prepared in our laboratory. RAM-FITC and SAR-FITC: conjugated rabbit-anti-mouse- and swine-anti-rabbit-immunoglobulins (Dakopatts, Denmark). DMEM (Dulbecco's modified Eagle's medium), penicillin, streptomycin, amphotericin B, L-glutamine (Biochrom $\mathrm{KG}$, Berlin, Germany), fetal calf serum (GIBCO-BRL).

\section{Mețhods}

\section{Cell culture}

Five millilitres of synovial fluid (cell density about $3 \times 10^{9} / \mathrm{l}$ ) were pipetted into each of 4 polystyrene-Falcon-3813 flasks $\left(25 \mathrm{~cm}^{2}-\right.$ $50 \mathrm{ml}$ ) and $2 \mathrm{ml}$ were pipetted into each of 2 Falcon-3802 dishes $(60 \mathrm{~mm} \times 15 \mathrm{~mm})$. The dishes were provided with Thermanox covers (Thermanox, Plano, Marburg, Germany). In addition, each flask contained $2.5 \mathrm{ml}$ and each dish $1 \mathrm{ml}$ DMEM containing 100 $\cdot 10^{3} \mathrm{IU} / \mathrm{l}$ penicillin, $100 \mathrm{mg} / \mathrm{l}$ streptomycin, $0.5-1.0 \mathrm{mg} / \mathrm{l}$ amphotericin $\mathrm{B}$ and $0.8 \mathrm{~mol} / \mathrm{l} L$-glutamine. In half of the flasks and dishes the medium was supplemented with fetal calf serum, volume fraction 0.1. This was followed by incubation at $37^{\circ} \mathrm{C}$ in an atmosphere of $95 \%$ air and $5 \% \mathrm{CO}_{2}$ for 24 hours. Thereafter, the synovial fluid was decanted from adherent cells and replaced by DMEM. Simultaneously, two flasks of each experiment (1 flask with medium plus fetal calf serum and 1 flask with medium without fetal calf serum) were continuously irradiated with an electromagnetic modulator the magnetic field of which amounted to $285 \pm 33 \mathrm{nT}$ (for 24 hours). To avoid scattering of rays, the flasks with the electromagnetic modulator were wrapped up in aluminum-foil. For each flask with an electromagnetic modulator, a control flask was used under the same conditions. The medium was changed every 24 hours and stored separately at $-20^{\circ} \mathrm{C}$. Cultivation was terminated after 2 weeks.

The magnetic induction was delivered by a commercial device ( $\mathrm{Fa}$ Mediline, Berlin/type Megawave 150 ) giving $10 \mu$ s pulses superimposed on an rf carrier of $0.500 \pm 0.005 \mathrm{MHz}$ frequency with pulse repetition rates adjustable in steps between 1.5 and $15 \mathrm{~Hz}$. The effective induction at $20 \mathrm{~mm}$ from the flat bottom of the transmitter (corresponding to the cell culture site) was monitored using a 10 turn $1 \mathrm{~cm}^{2}$ area pick-up coil connected to a $10 \mathrm{MHz}$ oscilloscope (fig. 1). The induction varied linearly between a value of $230 \mathrm{nT}$ amplitude at the flask bottom to $340 \mathrm{nT}$ at the flask neck. This can be expressed in terms of mean induction and root mean square value as:

$$
\overline{\mathrm{B}}=285 \mathrm{nT}, \Delta \mathrm{B}_{\mathrm{rms}}=33 \mathrm{nT} \text { (fig. 2). }
$$

At any repetition rate within the cited limits, the transmitter could be run up to 24 hours. The electromagnetic modulator used in our experiments produced naturally a mixture of electromagnetic field components: due to Maxwell's relations, the induction $\mathrm{B}(\mathrm{t})$ causes closed loops of electric field $E(t)$ with amplitude $\tilde{E}_{o}=\omega r B_{o}$ (r: represents the distance of a point in the sample plane from its centre). Assuming its mean value to be $\overline{\mathrm{r}}=25 \mathrm{~mm}$, then the mean value of $E_{o}$ is $\vec{E}_{o}=25 \pm 3 \mathrm{mV} / \mathrm{m}$. If we: compare the electric power density $\varepsilon_{0} \mathrm{E}_{\mathrm{o}}^{2} / 2=2.610^{-15} \mathrm{~W} \mathrm{~s} / \mathrm{m}^{3}$ with the corresponding magnetic power density $B_{0}^{2} / 2 \mu_{o}=3.610^{-8} \mathrm{~W} ~ s / m^{3}$, the magnetic density is $10^{7}$ times higher than the corresponding electric density. This finding suggests that the influence of such extremely weak electric fields on the cultures could be neglected, and the results obtained are merely due to the magnetic fields. 


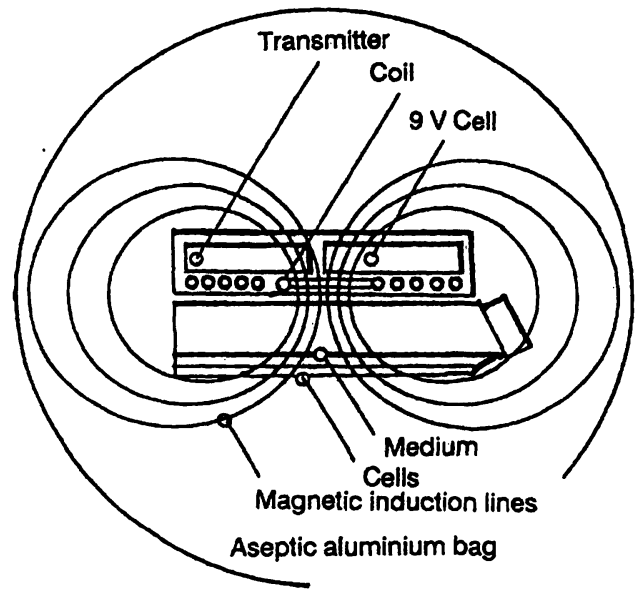

Fig. 1 Schematic demonstration of magnetic induction B perpendicular to the synovial cell cultures. The values of B vary slightly over the flask volume beneath the transmitter with transmitting coil incorporated (see fig. 2).

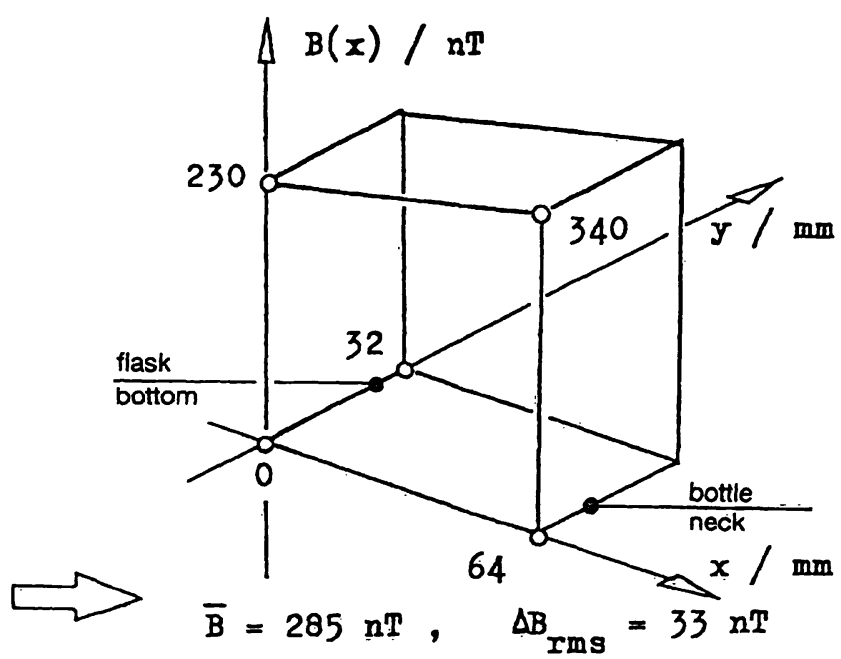

Fig. 2 Schematic representation of the homogeneity of the induction $B$ over the flask basis area. Whereas the dependence of $B$ along the $y$-axis is extremely small, its variation along the $x$-axis from its minimum value of $230 \mathrm{nT}$ at the bottom to its maximum value of $340 \mathrm{nT}$ at the bottleneck has to be taken into account.

\section{Electron microscopy}

The cultures grown on Thermanox covers were fixed in Karnovsky solution (for scanning electron microscopy), in 1\% tannic acid/ glutaraldehyde (for transmission electron microscopy), post-foxed with $1 \% \mathrm{OsO}_{4}$, dehydrated in graded ethannol and embedded in Epon. Sections were cut on a Reichert ultramicrotome, contrasted with uranyl acetate/lead citrate, examined atid photographed using a Zeiss EM 10 and a Siemens Elmiskop 101 electron microscope. For light microscopic examination a photomicroscope Axiophot and inversion-microscope IM (Zeiss) were used.

\section{Immunohistochemistry}

Cultures grown on Thermanox covers were snap-frozen in OCT compound (Miles Scientific Co., USA) and stored at $-70^{\circ} \mathrm{C}$ until required. Eight $\mu \mathrm{m}$ sections were cut on a cryostat at $-25^{\circ} \mathrm{C}$, mounted on gelatinized slides and allowed to dry. Sections were immediately fixed in methanol for $10 \mathrm{~min}$, rinsed $3 \times 5 \mathrm{~min}$ in phosphate buffered saline and subsequently incubated with the primary antibodies: anti-human-fibroblast- and anti-human-PMNL- gelatinases (diluted $1: 10$ ) for 1 hour at room temperature. Finally, the sections were rinsed $3 \times 5 \mathrm{~min}$ in phosphate buffered saline and incubated with second antibodies: RAM-FITC and SAR-FITC (diluted $1: 30$ ) for 1 hour at room temperature. After rinsing $3 \times 5$ min in phosphate buffered saline the slides were air-dried, coverslipped with glycerol, examined and photographed with a Universal microscope Acioplan (Zeiss).

\section{Enzyme activity measurements}

For this purpose the following synthetic substrates were used: $L$ alanine-p-nitroanilide (Ala-pNA) for aminopeptidases and $\mathrm{N}(2,4)$ dinitrophenyl-pro-Gln-Gly-Ile-Ala-Gly-GIn-D-Arg (N(2,4)-dinitrophenyl-peptide) for collagenase, gelatinase and some other proteinases. This N(2,4)-dinitrophenyl-peptide is hydrolysed by metalloproteinases (collagenase, gelatinase and stromelysin), endopeptidase EC 3.4.24.11, leukocyte elastase and a partially characterized metalloproteinase which is often called $\mathrm{N}(2,4)$-dinitrophenyl-peptidase.

Release of $p$-nitroaniline from Ala-p-nitranilide by the action of aminopeptidases is monitored by measurement of the absorbance at $405 \mathrm{~nm}\left(\varepsilon_{405 \mathrm{~nm}}=962 \mathrm{~m}^{2} / \mathrm{mol}\right)$. From the $\mathrm{N}(2,4)$-dinitrophenylpeptide, the other above-mentioned proteinases release $N(2,4)$-dinitrophenyl-peptide-Pro-GIn-Gly, the concentration of which can also be determined from the absorbance at $365 \mathrm{~nm}\left(\varepsilon_{365 \mathrm{~nm}}=1740\right.$ $\mathrm{m}^{2} / \mathrm{mol}$ ).

\section{Aminopeptidase activity measurements}

Four-hundred $\mu \mathrm{l}$ buffer $(50 \mathrm{mmol} / 1 \mathrm{Tris} / \mathrm{HCl}, 200 \mathrm{mmol} / \mathrm{l} \mathrm{NaCl}$, $5 \mathrm{mmol} / 1 \mathrm{CaCl}_{2}, 0.5 \mathrm{~g} / \mathrm{l} \mathrm{NaN}, \mathrm{pH} 7.0$ ) and $50 \mu \mathrm{l}$ substrate ( $5 \mathrm{mmol} / 1 L$-Ala-p-nitranilide buffer) were added to $50 \mu \mathrm{l}$ sample, incubated for 3 days at $37^{\circ} \mathrm{C}$, and the absorbance measured at A 405 nm (12).

\section{$N(2,4)$-Dinitrophenyl-peptidase activity measurements}

Collagenase, gelatinase and certain proteinases (which are not yet well defined) split the Gly-Ile bond of the synthetic substrate $\mathrm{N}(2,4)$-dinitrophenyl-Pro-GIn-Gly-Ile-Ala-Gly-Gln-D-Arg (N(2,4)dinitrophenyl-peptide). The released $\mathrm{N}(2,4)$-dinitrophenyl-peptidePro-Gln-Gly can be extracted with ethylacetate/ $n$-butanol. Concentration and activity of the enzyme can be determined by measuring the absorbance at $365 \mathrm{~nm}$. For this purpose, $50 \mu 1$ buffer $_{1}$ (see below) and $100 \mu$ l substrate $(N(2,4)$-dinitrophenyl-peptide, $500 \mathrm{mg} / \mathrm{l}$ buffer $_{2}$ ) were added to $50 \mu$ l sample and incubated for 18 hours at $37^{\circ} \mathrm{C}$. The reaction was terminated by adding $0.5 \mathrm{ml} 0.5 \mathrm{~mol} / \mathrm{l}$ $\mathrm{HCl}$, extracting the solution with $1 \mathrm{ml}$ ethylacetate $/ n$-butanol $(1+0.15$, by vol.) and centrifuging for $15 \mathrm{~min}$ at room temperature at $3000 \mathrm{~g}$. The organic phase was then measured at $365 \mathrm{~nm}$ (13).

Buffer $_{1}$ : $50 \mathrm{mmol} / 1 \mathrm{l}$ Tris $\mathrm{HCl}, 200 \mathrm{mmol} / \mathrm{l} \mathrm{NaCl}, 5 \mathrm{mmol} / \mathrm{CaCl}$, $0,55 \mathrm{~g} / 1 \mathrm{NaN}_{3}, \mathrm{pH} 7.0$

Buffer $_{2}: 0.5 \mathrm{~g} / 1$ bovine serum albumin in buffer 1 .

All the samples were measured against a mixture of $50 \mu$ substrate with $450 \mu$ l buffer ${ }_{1}$.

To investigate the sample, in particular with regard to collagenase (EC 3.4.24.7), $50 \mu \mathrm{l}$ samples were incubated with $50 \mu \mathrm{l}$ mersalyl and $100 \mu \mathrm{l}$ collagen type $\mathrm{I}\left(2 \mathrm{~g} / \mathrm{l}\right.$ buffer) for $18 \mathrm{~h}$ at $27^{\circ} \mathrm{C}$. SDSPAGE ( $8 \%$ gel) was then performed with $50 \mu$ l of this solution (14). 


\section{Results}

\section{Morphological findings}

In monolayer cultures of rheumatoid synovial fluid cells, cell adhesion was achieved very rapidly (within 2-3 hours). The cell populations on day 1 were very heterogeneous, consisting of macrophage-like cells, fibroblastlike cells, polymorphonuclear granulocytes and lymphocytes.

Polymorphonuclear granulocytes and lymphocytes, both of which initially occurred in abundance, disappeared quickly from the cultures, since the former have a short lifespan (15) and the latter were washed away from the cultures by the daily medium changes. The remaining adherent cells, which initially comprised macrophagelike cells and fibroblast-like cells with a varied number of polykaryocytes and dendritic cells (16), were then grown to confluency.

Macrophages, the proportion of which increased up to 1 week, represented the predominant cell type up to 2 weeks in most of the cultures. This finding is in accordance with results previously obtained by other authors (17) and may represent a specific behaviour of rheumatoid synovial fluid cells in vitro.

The macrophages seemed to be "active" as judged by their electron microscopic appearance. As revealed by transmission electron microscopy, they were characterized by a large cytoplasmic volume, an irregular surface with greatly varying processes and numerous cell organelles, especially primary and secondary lysosomes (fig. 3). Scanning electron microscopy showed round to elongated cells which characteristically exhibited membrane folding and ruffling with villous structures causing variations in surface morphology. This peculiar mem-

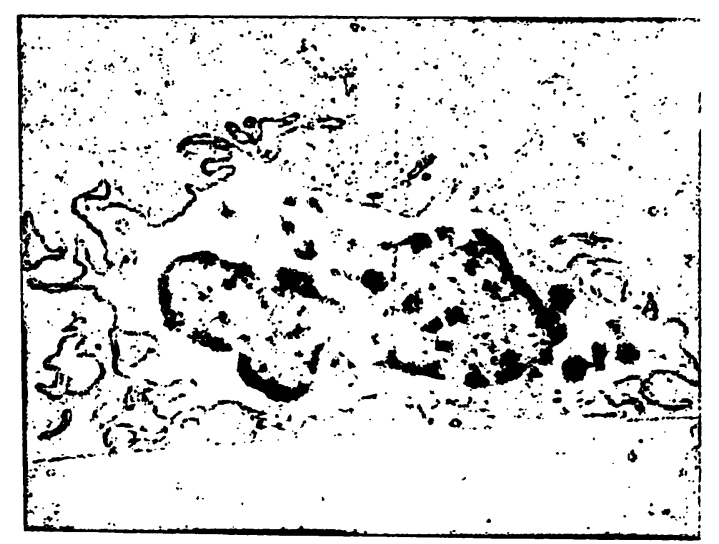

Fig. 3 Transmission electron microscopy of a synovial macrophage-like cell after 9 days in monolayer culture, showing extensive formation of characteristic macrophage surface processes, a large lobed nucleus and numerous cell organelles $(\times 2500)$.

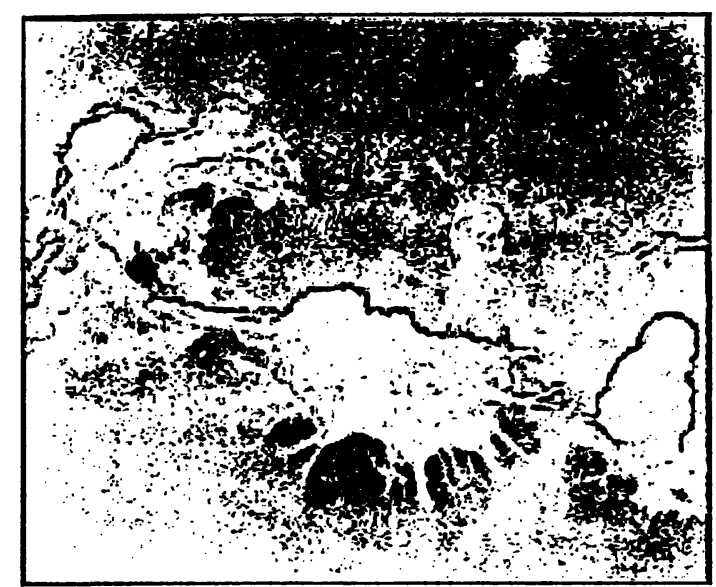

Fig. 4 Scanning electron microscopy of synovial macrophagelike cells on day 9 of monolayer culture. Note the bristly appearance of the cells due to the numerous filopodia $(\times 3000)$.

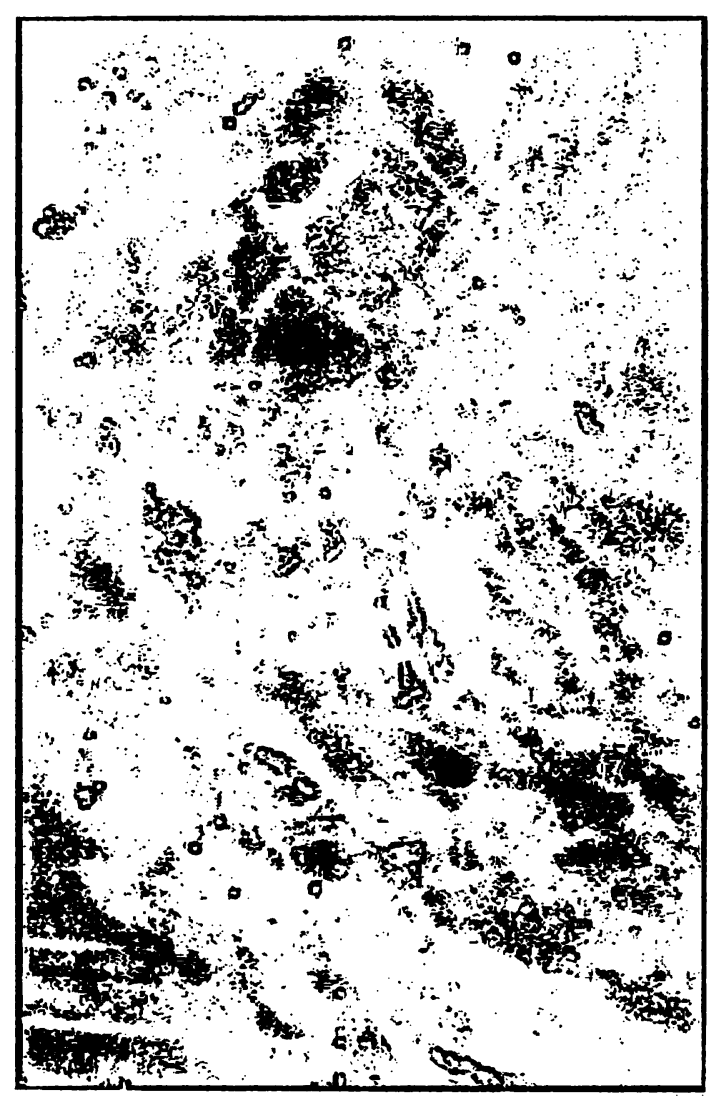

Fig. 5 Strong immunostaining of synovial macrophage-like cells by anti-PMNL-gelatinase $(\times 40)$.

-

brane appearance distinguishes macrophages from fibroblastic cells (fig. 4).

Fluorescence-microscopic investigations revealed further evidence for the macrophage origin of these cells. Immunohistochemical staining with anti-humanPMNL-gelatinase showed a strongly positive reaction (fig. 5). This finding may confirm the affiliation of the cells to synovial macrophages, since these cells synthesize a PMNL-type of gelatinașę (18). 


\section{Biochemical findings}

Since the enzyme activity in the culture medium can be measured from the 3rd/4th day onwards and reaches its peak on the 5 th/6th day in vitro $(2,19)$, the media of our short-term cultures ( 8 day the longest) were divided into two groups:

1) early phase-group ( $1 \mathrm{st}-3 \mathrm{rd}$ day)

2) late phase-group (from the 4th day onwards).

Since the enzyme activity decreases considerably towards the end of the 2nd week in culture (20), further activity measurements in the media of long-term cultures were not carried out. For the evaluation of the results the data were subdivided into 4 groups:

1) activity data measured in culture medium without serum

2) activity data measured in culture medium with serum (fetal calf serum, volume fraction 0.1 )

3) activity data measured in culture medium in the early phase (1st-3rd day) after previous irradiation with electromagnetic modulator (for 24 hours)

4) activity data measured in culture medium in the late phase (from 4th day onwards) after previous irradiation with electromagnetic modulator (for 24 hours).

We found that

a) in all media with and without fetal calf serum and with or without electromagnetic field treatment, aminopeptidase showed nearly the sāme activity and could be inhibited to the same extent with EDTA (tab. 1);

b) In the case of the $N(2,4)$-dinitrophenyl-peptidase the situation was slightly different:

Tab. 1 Aminopeptidase activity in culture medium with and without electromagnetic field irradiation.

\begin{tabular}{|c|c|c|c|c|}
\hline \multirow[t]{2}{*}{ Experiment } & \multicolumn{2}{|c|}{ Cultựe medium } & \multicolumn{2}{|c|}{ Aminopeptidase } \\
\hline & $\begin{array}{l}\text { Fetal } \\
\text { calf } \\
\text { serum }\end{array}$ & $\begin{array}{l}\text { Electro- } \\
\text { magnetic } \\
\text { modulator }\end{array}$ & $\begin{array}{l}\text { Activity } \\
\text { (U/i) }\end{array}$ & $\begin{array}{l}\text { Activity } \\
\text { after } \\
\text { inhibition } \\
\text { with } \\
\text { EDTA } \\
\text { (U/I) }\end{array}$ \\
\hline \multirow[t]{2}{*}{ No. 5} & $\begin{array}{l}\text { without } \\
\text { without }\end{array}$ & $\begin{array}{l}\text { without } \\
\text { with }\end{array}$ & $\begin{array}{l}0.090 \\
0.020\end{array}$ & $\begin{array}{l}0: 008 \\
0: 005\end{array}$ \\
\hline & $\begin{array}{l}\text { with } \\
\text { with }\end{array}$ & $\begin{array}{l}\text { without } \\
\text { with }\end{array}$ & $\begin{array}{l}0.084 \\
0.084\end{array}$ & $\begin{array}{l}0.010 \\
0.009\end{array}$ \\
\hline \multirow[t]{2}{*}{ No. 6} & $\begin{array}{l}\text { without } \\
\text { without }\end{array}$ & $\begin{array}{l}\text { without } \\
\text { with }\end{array}$ & $\begin{array}{l}0.075 \\
\text { not carri }\end{array}$ & $\begin{array}{l}0.005 \\
\text { out }\end{array}$ \\
\hline & $\begin{array}{l}\text { with } \\
\text { with }\end{array}$ & $\begin{array}{l}\text { without } \\
\text { with }\end{array}$ & $\begin{array}{l}0.087 \\
0.082\end{array}$ & $\begin{array}{l}0.010 \\
0.010\end{array}$ \\
\hline
\end{tabular}

I. In the media of the early phase (without fetal calf serum) the activity showed average values, and could be considerably activated with mersalyl. The activity was inhibited by EDTA and phosphoramidon (EDTA more than phosphoramidon) without perceptible influence of electromagnetic fields (tab. 2).

II. In the media of the late phase and in the pooled medium of 5 days (both without fetal calf serum) the activity was the same as in the media of the early phase, but could not be activated with mersalyl. It was, however, clearly inhibited by EDTA, but not, by phosphoramidon. Activity was considerably higher in the medium treated with electromagnetic fields than in the other media.

III. In the media of the late phase and in the pooled medium (both with fetal calf serum), however, the activity was very low, and was activated by mersalyl and inhibited by EDTA as well as phosphoramidon (EDTA more than phosphoramidon). In analogy with point II, the activities in the medium treated with electromagnetic fields appeared to be higher than in the media without electromagnetic modulator irradiation (tab. 2).

\section{Discussion}

Our data indicate that synovial fluid cells in monolayer culture developed into cells which ultrastructurally exhibited typical features of macrophages. This finding was confirmed by an intense diffuse staining for humanPMNL-gelatinase (EC 3.4.24.35), a pattern typical of synovial macrophages (18).

The measured activity of aminopeptidase shows that this enzyme is not influenced by fetal calf serum, or by electromagnetic waves of relatively low strength and frequency. The activity remains at the same level in the early and late phases.

This exopeptidase consists of a number of metalloenzymes, all characterized by their ability to hydrolytically remove $\alpha$-amino acids from the $\mathrm{N}$-terminus of the peptide chain (21). They mainly differ in their substrate specificity, can easily be inhibited by EDTA, and occur in numerous human tissues and organs (22).

The origin of this enzyme activity in our synovial culture appears to be unknown. The common view is that aminopeptidasses mainly occur in the hepatobiliary system, the pancreas, small intestine, stomach, lung, kidney, placenta (23), several malignant tumours of these organs (22), and leukocytes (24).

Since leukocytes are rather short-lived in culture and can no longer be demonstrated after 48 hours, the activity measured in all our culture media cannot be attributed to 
Tab. 2 N(2,4)-Dinitrophenyl-peptidase activity in culture medium with and without electromagnetic field irradiation.

\begin{tabular}{|c|c|c|c|c|c|c|}
\hline \multirow[t]{2}{*}{ Experiment } & \multicolumn{2}{|c|}{ Culture medium } & \multirow{2}{*}{$\begin{array}{l}\text { Prior to } \\
\text { activation }\end{array}$} & \multirow{2}{*}{$\begin{array}{l}\text { After } \\
\text { activation } \\
\text { with mersalyl }\end{array}$} & \multicolumn{2}{|c|}{ After inhibition with } \\
\hline & Serum & $\begin{array}{l}\text { Electro- } \\
\text { magnetic } \\
\text { modulator }\end{array}$ & & & $\begin{array}{c}\text { EDTA } \\
\quad \text { i }\end{array}$ & Phosphoramidon \\
\hline \multirow[t]{2}{*}{ No. 5} & $\begin{array}{l}\text { without } \\
\text { without }\end{array}$ & $\begin{array}{l}\text { without } \\
\text { with }\end{array}$ & $\begin{array}{l}0 \\
0\end{array}$ & $\begin{array}{l}0.031 \\
0\end{array}$ & $\begin{array}{l}0 \\
0\end{array}$ & 0 \\
\hline & $\begin{array}{l}\text { with } \\
\text { with }\end{array}$ & $\begin{array}{l}\text { without } \\
\text { with }\end{array}$ & $\begin{array}{l}0.035 \\
0.020\end{array}$ & $\begin{array}{l}0.069 \\
0.045\end{array}$ & $\begin{array}{l}0 \\
0\end{array}$ & 0 \\
\hline \multirow[t]{2}{*}{ No.6 } & $\begin{array}{l}\text { without } \\
\text { without }\end{array}$ & $\begin{array}{l}\text { without } \\
\text { with }\end{array}$ & \multicolumn{4}{|c|}{ not carried out } \\
\hline & $\begin{array}{l}\text { with } \\
\text { with }\end{array}$ & $\begin{array}{l}\text { without } \\
\text { with }\end{array}$ & $\begin{array}{l}0.022 \\
0.047\end{array}$ & $\begin{array}{l}0.057 \\
0.163\end{array}$ & $\begin{array}{l}0 \\
0.020\end{array}$ & 0.035 \\
\hline \multirow[t]{2}{*}{ No. 14} & $\begin{array}{l}\text { without } \\
\text { without }\end{array}$ & $\begin{array}{l}\text { without } \\
\text { with }\end{array}$ & $\begin{array}{l}\text { F: } 0.128 \\
\text { S: } 0.128 \\
\text { F: } 0.118 \\
\text { S: } 0.423\end{array}$ & $\begin{array}{l}0.259 \\
0.128 \\
0.244 \\
0.407\end{array}$ & $\begin{array}{l}0 \\
0 \\
0 \\
0\end{array}$ & $\begin{array}{l}0.020 \\
0.122 \\
0.020 \\
0.416\end{array}$ \\
\hline & $\begin{array}{l}\text { with } \\
\text { with }\end{array}$ & $\begin{array}{l}\text { without } \\
\text { with }\end{array}$ & $\begin{array}{l}\text { F: } 0.118 \\
\text { S: } 0.031 \\
\text { F: } 0.145 \\
\text { S: } 0.045\end{array}$ & $\begin{array}{l}0.354 \\
0.049 \\
0.306 \\
0.098\end{array}$ & $\begin{array}{l}0 \\
0 \\
0 \\
0\end{array}$ & $\begin{array}{l}0.031 \\
0.018 \\
0.018 \\
0.012\end{array}$ \\
\hline
\end{tabular}

F: Medium of the early phase

$\mathrm{S}$ : Medium of the late phase

leukocyte-aminopeptidases. It may therefore be assumed that in rheumatoid arthritis the synovial cells are able to synthesize aminopeptidases in addition to several known proteinases. This finding requires further elucidation, possibly by employing specific antibodies against certain aminopeptidases.

The N(2,4)-dinitrophenyl-peptidase shows a clear-cut difference in activity between early and late phase:

In the early phase the enzyme shows a relatively high activity. It can be further activated with mersalyl (indicating probably a partial latency of this enzyme) and can clearly be inhibited by EDTA and phosphoramidon.

Since phosphoramidon inhibits numerous metalloproteinases, including thermolysin and proteinase 24.11 (a wide-spread membrane-bound metalloproteinase), not, however, collagenase and gelatinase $(25,26)$, this finding indicates that we are obviously dealing with several metalloproteinases. Effects of the electromagnetic fields and fetal calf serum are not observed.

The situation in the late phase is completely different. A certain correlation with the serum content and electromagnetic irradiation is perceptible. In the media without fetal calf serum the enzymes obviously occur only in their active form. They cannot be activated by mersalyl. They can be inhibited by EDTA, not, however, by phosphoramidon. This appears to indicate that the proteinases inhibitable with phosphoramidon (metalloproteinase
24.11, for example) are no longer present in the late phase. In the media with fetal calf serum the activity is low and shows a slight increase with mersalyl and a clear-cut inhibition by EDTA. A pronounced inhibition by phosphoramidon is not detectable (tab. 2).

Inhibition of all the activities against $\mathrm{N}(2,4)$-dinitrophenyl-peptide by EDTA indicates the absence of leukocyte elastase in the samples, since this serine protease cannot be inhibited by EDTA.

The fact that mersalyl did not cause any reduction of activities also indicates the absence of the so-called $\mathrm{N}(2,4)$-dinitrophenyl-peptidase (inhibitable by merșalyl).

Generally, activation of the samples by mersalyl is evidence of the presence of metalloproteinases which cannot be further distinguished by $\mathrm{N}(2,4)$-dinitrophenylpeptide or even with the help of inhibitors.

In the two groups of the late phase (medium with and without fetal calf serum) that were irradiated with the electromagnetic modulator, the enzyme activity is higher than in the media without irradiation. This effect of a weak strength and low frequency electromagnetic fields on metalloproteinases has not previously been described, and it is especially pronounced in the media without fetal calf serum.

The low activity in the media with fetal calf serum might be the result of an inhibition by various serum anti-pro- 
teinases. Some of these serum proteins $\left(\alpha_{2}\right.$-macroglobulins, for example) have a broad spectrum and inhibit several proteinases (27). Others (e. g. $\beta_{1}$-anticollagenase) are specific for only one proteinase $(28,29)$. These inhibitors partly form stable complexes with the corresponding enzymes, thus often causing irreversible inhibition of their activity (30-32).

Similar findings with human serum in cultures of rabbit synovia have already been reported (2). A certain functional analogy between the macroglobulins of human and mammalian sera with respect to proteinase inhibition is assumed $(27,33,34)$.

Not only the serum antiproteinases but also the tissue inhibitor of metalloproteinases synthesized by synovial cells (35) may play a role in the inhibition of the enzyme activity in our cultures.

As observed in our experiments, the increase of enzyme activity in the media without fetal calf serum, due to electromagnetic fields, clearly differs from the findings of other authors for long-term treatment with electromagnetic fields'(strength: 1.6-3.2 $\mathrm{mT}$; frequency: $15-$ $72 \mathrm{~Hz}$ ). In these experiments changes of some lysosomal enzymes, such as glucuronidase and $\mathrm{N}$-acetyl-glucosaminidase were observed, but the metalloproteinases re-

\section{References}

1. Henderson, B. \& Edwards, J. C. W. (1987) The Synovial Lining in Health and Disease, pp. 289-341, Chapman and Hall, London.

2. Werb, Z. \& Burleigh, M. C. (1974) A specific collagenase from rabbit fibroblasts in monolayer culture. Biochem. J. 137, 373-385.

3. McGuire, M. K. B., Murphy, G., Ebsworth, N. M., Meats, J. E., Reynolds, J. J. \& Rụssell, R. G. G. (1981) Factors influencing production of enzymes by human synovium in vitro. In: $A r-$ ticular Synovium (Franchimoni, P., ed.) pp. 75-94, Int. Symp., Burges, Karger, Basel.

4. Presman, A. S. (197.0) Electromagnetic Fields. Plenum Press, New York-London.

5. Murray, J. C. \& Lacy, M. (1983) Transactions of the Annual Meeting of Bioelectrical Repair and Growth Society, 1983; 3:7. Cited in: Interactions Between Electromagnetic Fields and Cells (Chiabrera, A., Nicolini, C. \& Schwwan, H. P., eds.) Series A: Life Sciences 97, 543.

6. Farndale, R. W. (1984) PhD thesis CNAA. Cited in: Biophysical Studies of Pulsed Magnetic Field Interaction with Biological Systems by Fitton Jackson, S. In: Interaction Between Electromagnetic Fields and Cells (Chiabrera, A., Nicolini, C. \& Schwan, H. P., eds.) Series A: Life Sciences 97, 543.

7. Sacchitelli, G. \& Sacchitelli, F. (1956) L'azione delle microonde radar sulla plasmalipasi e sull'amilasi serica. Folia Med. 39, 1037. Cited in: Electromagnetic Fields and Life (Presman, A. S., ed.) p. 137, Plenum Press, New York-London.

and Sacchitelli; G. \& Sacchitelli, F. (1958) Sul copartmento della glutationemia in seguito ad irradiazioni con microonde radar. Folia Med. 41, 342. Cited in: Electromagnetic Fields and Life mained unchanged (5). From our experiments it is not yet clear whether our findings are due to a special delayed effect of a single irradiation or whether they represent a certain peculiarity of proteinases in the rheumatoid synovia. In any case, the absorption of magnetic field resonance by enzyme molecules should play an important role. Some authors assume $(36,37)$ that resonance absorption induces a change in the distribution of protons within the enzyme molecule thus indirectly influencing the rate of formation of the enzyme-substrate complex and enzyme activity. The different response of various enzymes to electromagnetic fields in vitro might be attributed to the inhomogeneous behaviour of macromolecules in this respect. While some enzymes, such as lysozyme (36), $\alpha$-amylase (38), catalase and peroxidase $(8,9)$ react to electromagnetic fields of high strength and frequency with a pronounced decrease in activity, others, such as trypsin (39) and carboxydismutase (40) show an increase in activity due to irradiation with electromagnetic modulator. Similar mechanisms might also be responsible for our results.

\section{Acknowledgement}

This work was supported by grants from the Deutsche Forschungsgemeinschaft awarded to Sfb 174. The authors are indebted to Mrs. Barbara Steyn for help with the manuscript.
(Presman, A. S., ed.) p. 137, Plenum Press, New York-London.

8. Chirkov, M. M. (1964) The effect of the energy of electromagnetic vibrations of the acoustic spectrum on catalase activity of blood. In: Some Questions of Physiology and Biophysics, Voronezh, 1965, p. 25. Cited in: Electromagnetic Fields and Life (Presman, A. S., ed.) p. 173, Plenum Press, New YorkLondon, 1970.

9. Chirkov, M. M. (1970) Authors abstract of candidate's dissertation: The effect of the energy of electromagnetic vibrations of the audio- and radio-frequency ranges on the catalase and peroxidase activity of rabbit blood and rat tissues. Voronezh, 1965. In: Electromagnetic Fields and Life (Presman, A. S., ed.) p. 173, Plenum Press, New York, 1970.

10. Fitton Jackson, S. (1987) Biophysical studies of pulsed magnetic field interaction with biological systems. Part I: Biophysical interactions. In: Interaction Between Electromagnetic Fields and Cells (Chiabrera, A., Nicolini, C. \& Schwan, H. P., eds.) Series A: Life Sciences 97, 537-545.

11. Harris, E. D., Jr. \& Krane, S. M. (1974) Collagenases. New Engl. J. Med. 291, 557-661.

12. Rautenberg, W. \& Tschesche, H. (1984) Aminopeptidases from human leucocytes. Hoppe-Seyler's Z. Physiol. Chem. 365, 49-58.

13. Masui, Y., Takemoto, T., Sakakibara, S., Hori, H. \& Nagai, Y. (1977) Synthetic substrates for vertebrate collagenase. Biochem. Med. 17, 215-221.

14. Laemmli, U. K. (1970) Cleavage of structural proteins during assembly of the head of bacteriophage T4. Nature 227, 680 .

15. D'Onofrio, C. \& Paradisi, F. (1983) In-vitro differentiation of human monocytes into macrophages during long-term cultures. Immunobiology 164, 13-22. 
16. Mohamed-Ali, H., Hauer, R. W. \& Sörensen, H. (1991) Morphologie und Wachstumsverhalten von Synoviazellen in der Monolayer-Kultur. Z. Rheumatol. 50, 74-81.

17. Palmer, D. G. (1971) The differentiation of cells cultured from synovial effusions. Proc. Univ. Ottago Med. Schr. 49, 18-19.

18. Kolkenbrock, H., Mohamed-Ali, H., Hecker-Kia, A., Buchlow, G., Sörensen, H., Hauer, R. W. \& Ulbrich, N. (1991) Characterization of a gelatinase from human rheumatoid synovial fluid cells. Eur. J. Clin. Chem. Clin. Biochem. 29, 499-505.

19. Evanson, J. M., Jeffrey, J. J. \& Krane, S. M. (1968) Studies on collagenase from rheumatoid synovium in tissue culture. J. Clin. Invest. 47, 2639-2651.

20. Dayer, J. M., Krane, S. M., Graham, R., Russel, G. \& Robinson, D. R. (1976) Production of collagenase and prostaglandins by isolated adherent rheumatoid synovial cells. Proc. Natl. Acad. Sci. USA 73, 945-949.

21. Hafkenscheid, J. C. M. (1984) Aminopeptidases and amino acid arylamidases. In: Methods of Enzymatic Analysis (Bergmeyer, H. U., ed.) Verlag Chemie, Weinheim, Vol. 5, pp. 2-10.

22. Tamura, Y., Niiobe, M., Arima, T., Okuda, H. \& Fujii, S. (1975) Aminopeptidases and arylamidases in normal and cancer tissues in humans. Cancer Res. 35, 1030-1034.

23. Hiwada, K., Terao, M., Nishimura, K. \& Kokubu, T. (1.977) Comparison of human membrane-bound neutral arylamidases from small intestine, lung, kidney, liver and placenta. Clin. Chim. Acta 76, 267-275.

24. Engelbrecht, S., Pieper, E., Macartney, H. W., Rautenberg, W., Wenzel, H. R. \& Tschesche, H. (1982) Separation of the human leucocyte enzymes alanine aminopeptidase, cathepsin G, collagenase, elastase and myeloperoxidase. Hoppe-Seyler's Z. Physiol. Chem. 363, 305-315.

25. Bond, J. S. \& Begnon, R. J. (1985) Mammalian metalloendopeptidases. Int. J. Biochem. 17, 565-574.

26. Williams, H. R. \& Tsau-Yen Lin (1984) Human polymorphonuclear leucocyte collagenase and gelatinase. Int. J. Biochem. $16,1321-1329$.

27. Woolley, D. E. \& Evanson, J. M. (1980) Collagenase in Normal and Pathological Connective Tissues. A. Wiley Interscience Publication, New York.

28. Woolley, D. E., Roberts, R. D. \& Evanson, J. M. (1976) Small molecular weight $\beta_{1}$ serum protein which specifically inhibits human collagenases. Nature 261, 325-327.
29. Woolley, D. E., Akroyd, C., Evanson, J. M., Soames, J. V. \& Davies, R. M. (1978) Characterisation and serum inhibition of neutral collagenase from cultured dog gingival tissue. Biochem. Biophys. Acta 522, 205-217.

30. Barrett, A. J. \& Starkey, P. M. (1973) The interaction of $\alpha$ macroglobulin with proteinases. Characteristics and specificity of the reaction, and a hypothesis concerning its molecular mechanism. Biochem. J. 133, 709 -724 .

31. Harpel, P. C. (1973) Studies on human plasma $\alpha_{2}$-macroglobulin-enzyme interactions. J. Exp. Med. 138, 508-521.

32. Berman, M. B. (1976) The role of $\alpha$-macroglobulins in corneal ulceration. In: Progress in Clinical and Biological Research. Trace Components of Plasma: Isolation and Clinical Significance (Jamieson, G. A. \& Greenwalt, T. J., eds.) Vol. 5, pp. 225-253, Alan R. Liss, New York.

33. Bourrillon, R. \& Razafimahaleo, E. (1972) $\alpha_{2}$-Macroglobulins. In: Glycoproteins (Gottschalk, A., ed.) 6/4, pp. 700-716, Elsevier, New York.

34. Lebreton de Vonne, T. \& Mouray, H. (1974) Ann. Biol. Clin. 32, 185-196. Cited in: Collagenase in Normal and Pathological Connective Tissues. (Woolley, D. E. \& Evanson, J. M., eds.) p. 161. A Wiley Interscience Publication, New York, 1980.

35. Cawston, T. E., Galloway, W. A., Mercer, E., Murphy, G. \& Reynolds, J. J. (1981) Purification of rabbit bone inhibitor of collagenase. Biochem. J. 195, 159-165.

36. Vogelhut, P. (1960) Study of enzymatic activity under the influence of 3-cm electromagnetic radiation. In: Third International Conf. Med. Electronics, p. 52.

37. Prausnitz, S., Süsskind, C. \& Vogelhut, P. O. (1961) Longevity and cellular studies with microwaves. In: Biological Effects of Microwave Radiation. Vol. 1, pp. 135-142, Plenum Preșs, New York.

38. Bach, S. (1965) Biological sensitivity to radiofrequency and microwave energy. Federation Proc. 24, 22.

39. Cook, E. \& Smith, S. M. J. (1964) Increase of trypsin activity. In: Biological Effects of Magnetic Fields. pp. 246-254, Plenum Press, New York.

40. Akoyunoglou, G. (1964) Effect of a magnetic field on carboxydismutase. Nature 202, 452-454.

Dr. H. Mohamed-Ali

Institut für Anatomie

Freie Universität Berlin

Königin-Luise-Straße 15

D-14195 Berlin

Germany 